Article

\title{
Effect of Musts Oxygenation at Various Stages of Cider Production on Oenological Parameters, Antioxidant Activity, and Profile of Volatile Cider Compounds
}

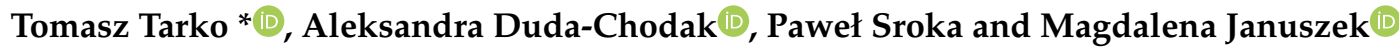 \\ Department of Fermentation Technology and Microbiology, Faculty of Food Technology, University of \\ Agriculture in Krakow, ul. Balicka 122, 30-149 Krakow, Poland; a.duda-chodak@ur.krakow.pl (A.D.-C.); \\ p.sroka@ur.krakow.pl (P.S.); magdalena.kostrz@urk.edu.pl (M.J.) \\ * Correspondence: t.tarko@ur.krakow.pl; Tel.: +48-12-6624792
}

Received: 18 May 2020; Accepted: 8 June 2020; Published: 10 June 2020

\begin{abstract}
The micro-oxygenation of musts may affect the quality of a finished alcoholic beverage. The aim of this study was to determine the effect of micro-oxygenation at various stages of fermentation on oenological parameters, antioxidant activity, total polyphenol content, and profile of volatile cider compounds fermented with various yeast strains. Rubin cultivar must was inoculated with wine yeast, cider yeast, distillery yeast, and wild yeast strains. Some of the inoculated samples were oxygenated immediately after yeast inoculation, and some on the second and third fermentation days. The control sample was non-oxygenated must fermented in bottles. Higher extract concentration and acidity as well as lower potency were observed in cider treated with micro-oxygenation. Must oxygenation in most cases contributed to the reduction of polyphenol content and to the antioxidant activity of ciders, especially when fermented using wild yeast. The oxygenation of musts before fermentation caused an increase in the content of esters and alcohols in ciders. However, the oxygenation of musts during fermentation reduced the concentration of these volatile components. The oxygenation of musts during fermentation produced a differentiated effect on terpenoid concentration in ciders.
\end{abstract}

Keywords: micro-oxygenation; cider; antioxidant activity; volatile compounds

\section{Introduction}

Alcohol fermentation plays a major role in the production of wines and ciders. It is an anaerobic process, therefore excessive amounts of oxygen can stop the fermentation. Contact with oxygen is usually considered to be a negative factor affecting the final quality of wines and ciders. Polyphenolic compounds, which are precursors of many compounds responsible for the color, taste, and aroma of wines and ciders, react with oxygen and get degraded, which adversely affects the sensory properties of wines, especially white wines. In the presence of oxygen, polymerization of polyphenolic compounds occurs, which leads to the formation of dark-colored components (from yellow to brown). The consequence of this process is the darkening of young wines, which is unacceptable for white wines. Exposure of musts for white wine to oxygen has a destructive effect on wine's aroma, as the compounds responsible for the fresh, fruity aroma of wine are easily oxidized [1,2]. Despite the greater buffering capacity of musts from red grape varieties in relation to oxygen, even they can undergo adverse changes upon contact with oxygen. High oxygen concentrations can cause oxidation of polyphenolic compounds and their precipitation in the form of sediment. During ripening, polyphenolic compounds play a huge role in creating color and appropriate taste sensations (fullness and astringency). Oxidation 
of polyphenolic compounds reduces their concentration in the final product and, as a consequence, negatively affects its quality [3].

However, it is necessary to stress the need to add small amounts of oxygen to the must before fermentation, as this contributes to the proper cell structure of yeast. Yeast cells need oxygen to produce sterols (mainly ergosterols) and unsaturated fatty acids, which play an important role in the fluidity and activity of membrane-associated enzymes that influence ethanol tolerance, fermentative capability, and the viability of yeast [2,4]. In addition, the use of an appropriate dose of oxygen can reduce the formation of sulfur compounds and shorten the fermentation time, which is probably associated with a greater resistance of yeast cells to ethanol $[1,5]$. Oxidation of must also affects the synthesis of volatile compounds by yeasts. Esters (including acetates and ethyl esters), higher alcohols, medium-chain fatty acids, aldehydes, or ketones formed during the fermentation stage are responsible for creating the color and aroma of wines [6,7].

Micro-oxygenation accelerates wine maturation and is most often used for wines with a high tannin content. Oxygen can modify the sensory properties of wine (taste, smell, and color), which is primarily due to its strong oxidizing properties. Terpenes, polyphenols, and other compounds that are constituents of wine are susceptible to oxidation reactions, which consequently affects a drink's composition $[2,8-10]$.

The aim of this study was to determine the effect of micro-oxygenation at various stages of fermentation on oenological parameters, antioxidant activity, total polyphenol content, and profile of volatile cider compounds fermented with various yeast strains.

\section{Materials and Methods}

\subsection{Ciders Preparation}

The apples (Rubin cultivar) used in these experiments were obtained from a pomological orchard of the University of Agriculture, located in Garlica Murowana (near Krakow, Poland). The apples were washed, ground, and pressed on a Zottel hydraulic press $(35 \mathrm{~L})$. The musts $(0.5 \mathrm{~L})$ obtained from particular cultivars were poured into bottles $(0.7 \mathrm{~L})$. The musts were then inoculated with various yeast strains (Erbslöh, Geisenheim, Germany): wine (Elegance), cider (Gozdawa), distillery (Ethanol RED), or wild (Wild \& Pure) at $0.2 \mathrm{~g} / \mathrm{L}$ (dry yeasts were hydrated according to the manufacturer's recommendations). One part of the samples was oxygenated through in-system sterile air barbotage to the bottles: $10 \mathrm{~s}$ oxygenation followed by a $10 \mathrm{~s}$ interval, for $1 \mathrm{~h}$ (air flow $1.6 \mathrm{~L} / \mathrm{min}$, this stage is referred to as must oxygenation). The bottles with the inoculated must were closed with glycerin-filled fermentation tubes and then allowed to ferment for two weeks at $20^{\circ} \mathrm{C}$. Other samples were oxygenated as above on the second and third day of fermentation (oxygenation during fermentation), while the control samples consisted of non-oxygenated musts fermented in bottles. The ciders were drained from the yeast sludge and aged at $4{ }^{\circ} \mathrm{C}$ for three weeks. All experiments were performed in triplicate.

\subsection{Determination of Total Acidity, Volatile Acidity, Total Extract Content, and Ethyl Alcohol Content}

The determination of total extract content, ethyl alcohol content, total acidity, and volatile acidity was conducted in accordance with the methods recommended by the International Organisation of Vine and Wine [11]. Total extract content and ethanol content in ciders were determined by distillation methods using pycnometric density determination, total acidity was determined with the potentiometric method, and volatile acidity was determined using the titration method. All experiments were performed in triplicate.

\subsection{Free Amino Nitrogen (FAN) Content}

Free amino nitrogen (FAN) was determined with the ninhydrin method. The absorbance of the samples was measured at a wavelength $\lambda=575 \mathrm{~nm}$ [12]. All experiments were performed in triplicate. 


\subsection{Antioxidant Activity}

The antioxidant capacity of the samples was determined by the diammonium salt of 2,2'-azino-bis (3-ethylbenzothiazoline-6-sulfonic) acid (ABTS) cation radical scavenging assay [13]. Active ABTS was produced through a chemical reaction with potassium persulfate. The absorbance was measured spectrophotometrically at $734 \mathrm{~nm}$. The results obtained were compared with the those obtained for Trolox (synthetic vitamin E) and expressed as mg Trolox/100 mL (TEAC, Trolox Equivalent Antioxidant Capacity). Absorbance measurements were performed on a UV-VIS Beckman spectrophotometer (type DU 650). All experiments were performed in triplicate.

\subsection{Total Polyphenol Content}

The total polyphenol content was determined with a spectrophotometric method (UV-VIS Beckman spectrophotometer) with Folin-Ciocalteu reagent [13]. The results of the total polyphenols were expressed as catechin equivalent $(\mathrm{mg} / 100 \mathrm{~mL})$, based on a standard curve. All experiments were performed in triplicate.

\subsection{Analysis of Polyphenolic Compound Profiles}

Prior to analysis, the samples were filtered through a nylon syringe filter $(0.45 \mu \mathrm{m}$, Chemland, Stargard Szczecinski, Poland). The analysis of the polyphenol profiles was carried out using a high-performance liquid chromatographer (HPLC, Shimadzu, Japan) equipped with a DAD detector. The Synergi Fusion RP-80A column $150 \mathrm{~mm} \times 4.6 \mathrm{~mm}(4 \mu \mathrm{m})$ (Phenomenex, Torrance, California, USA), thermostated at $30{ }^{\circ} \mathrm{C}$, was used for all analyses. Acetonitrile (POCh Gliwice) and a $2.5 \%$ aqueous solution of acetic acid (POCh) were used as a mobile phase. The gradient program and detection wavelengths are described in detail by Tarko et al. [14].

For quantitative analyses, calibration curves were prepared for the following standards: ferulic acid, caffeic acid, chlorogenic acid, gallic acid, hippuric acid, $p$-coumaric acid, protocatechuic acid, ellagic acid, (+)-catechin, quercetin, resveratrol, kaempferol (Sigma Aldrich), phloridzin, (-)-epicatechin, procyanidins B1 and B2, cyanidin-3-O-galactoside, cyanidin-3-O-sambubioside, cyanidin-3-O-arabinoside, cyanidin-3-O-glucoside, delphinidin-3-O-glucoside, quercetin-3-O-rutinoside, quercetin-3-O-glucoside, pelargonidin-3-O-glucoside, and peonidin-3-glucoside (Extrasynthese, Genay, France). Compounds were identified by comparing the retention time of individual peaks and UV spectra with those of the standards (using the spectrum library for the standards). Polyphenols not detected in any experimental variants were not included in the tables. All experiments were performed in triplicate.

\subsection{Analysis of Volatile Compounds}

The volatile compounds were determined using a modified Grützman et al. [15] method. A sample of $2 \mathrm{~mL}$ was placed into a $15 \mathrm{~mL}$ headspace vial, and $50 \mu \mathrm{L}$ of an internal standard solution $(5 \mathrm{mg} / \mathrm{L}$ of ethyl nonanoate) was added. Then a solid-phase microextraction (SPME) fiber ( $85 \mu \mathrm{m}$ Carboxen Polydimethylsiloxane, Supelco, St. Louis, MI, USA) was placed in the headspace above the sample, and the vial was incubated for 30 minutes at $40{ }^{\circ} \mathrm{C}$. The fiber was subjected to thermal desorption in a gas chromatographic injector at $250^{\circ} \mathrm{C}$.

The chromatographic separation was carried out on a Clarus 580 apparatus equipped with a flame ionization detector (FID) (PerkinElmer, Walthman, MA, USA) and a Crossbond dimethylpolysiloxane column ( $60 \mathrm{~m}$ in length, $0.25 \mathrm{~mm}$ of inner diameter, $1.4 \mu \mathrm{m}$ of film thickness, Restek, Bellefonte, PA, USA). The carrier gas flow (He) was $2 \mathrm{~mL} / \mathrm{min}$, and the temperature program was: $35^{\circ} \mathrm{C}, 6 \mathrm{~min}$; $8{ }^{\circ} \mathrm{C} / \mathrm{min}$ up to $180^{\circ} \mathrm{C} ; 12{ }^{\circ} \mathrm{C} / \mathrm{min}$ up to $220^{\circ} \mathrm{C} ; 25 \mathrm{~min}$. The inlet and FID temperature was $250^{\circ} \mathrm{C}$. An HT2800T autosampler (HTA Brescia, Italy) was used, and PerkinElmer Total Chrom 6.3.2 software (PerkinElmer, Walthman, MA, USA) was used to integrate the results. Identification was performed based on the retention times compared with those of the standards for the volatile compounds, 
and quantification was carried out by internal standardization, using 4-methyl-2-pentanol (alcohols) and ethyl nonanoate (esters) as the internal standards. The standard solutions were prepared in synthetic wine (20 g/L sucrose, $5 \mathrm{~g} / \mathrm{L}$ tartaric acid, $10 \%$ ethanol). All experiments were performed in triplicate.

\subsection{Analysis of Terpenoids}

A $40 \mathrm{~mL}$ sample was measured into a test tube $(50 \mathrm{~mL}) ; 100 \mu \mathrm{L}$ of internal standard solution ( $5 \mathrm{mg} / \mathrm{L}$ anethol) and $4 \mathrm{~mL}$ of hexane were added, and extraction was performed on a rotary shaker (350 cpm, amplitude 3, $1 \mathrm{~h}$ ). Then, the hexane layer was removed, transferred to the equation vessels, and centrifuged $(2154 \times g, 10 \mathrm{~min})$. The hexane layer was collected, and the chromatographic analysis was performed.

The separation was carried out using an HP 5820 camera, a Stabilwax column ( $30 \mathrm{~m}, 0.25 \mathrm{~mm})$ and a FID. The carrier gas flow (He) was $2 \mathrm{~mL} / \mathrm{min}$, and the temperature program was: $35^{\circ} \mathrm{C}$ for $1 \mathrm{~min}$, increased by $4{ }^{\circ} \mathrm{C} / \mathrm{min}$ up to $250{ }^{\circ} \mathrm{C}$; then held at $250{ }^{\circ} \mathrm{C}$ for $5 \mathrm{~min}$. The detector and dispenser temperature was $250^{\circ} \mathrm{C}$. An HT3000A autosampler (from HTA company, Brescia, Italy) was used, and the results were integrated using Clarity 7.2 software from DataApex Ltd. All experiments were performed in triplicate.

The limit of detection (LOD) for the analyzed terpenoids was $0.003 \mathrm{mg} / \mathrm{L}$, and the limit of quantification (LOQ) was $0.01 \mathrm{mg} / \mathrm{L}$.

\subsection{Statistical Analysis}

There were at least three physical repetitions of each experimental setting. All samples were analyzed once, but in the case of discrepancies in the results, the analysis was repeated. Results are shown as the arithmetic mean with standard deviation $( \pm \mathrm{SD})$. The statistical analysis was performed using InStat v.3.01 (GraphPad Software Inc., USA). A single-factor analysis of variance (ANOVA) with post-hoc Tukey's test was applied to determine the significance of differences. The Kolmogorov-Smirnov test was carried out to assess the normality of distribution.

\section{Results and Discussion}

\subsection{The Effect of Oxygenation on Oenological Parameters of Ciders}

Alcohol concentration depends primarily on the amount of fermentable sugars in the must and on the type of yeast. Ciders can contain from $1.2 \%$ to $8.5 \%$ of alcohol. The obtained results were in this range, as expected. The must extract before fermentation was about $130 \mathrm{~g} / \mathrm{L}$, and its content in ciders ranged from 16.43 to $18.8 \mathrm{~g} / \mathrm{L}$. The loss of extract (the amount of fermented sugars) was consistent with the amount of alcohol produced by the yeast and depended on the type of yeast used.

Based on the results obtained, it can be concluded that the use of oxygenation significantly reduced the concentration of ethanol in the tested samples (by about 10-15\% compared to the control samples) (Table 1). Similar results were presented by Sirén et al. [16], showing a reduction in the concentration of ethanol in oxygenated wines, compared to controls. The lower concentration of ethanol in cider may be associated with oxidative stress of yeast during fermentation, resulting from oxygenation. Oxidative stress is one of the main causes of early death of yeasts during the fermentation process [1]. Furthermore, the reduction in ethanol concentration may be due to its oxidation to acetaldehyde [17]. During oxidation, the formation of acetaldehyde from ethanol would promote the formation of ethyl bridges between flavanols and between flavanols and anthocyanins [18]. The decrease in ethanol concentration may also be caused by the increased use of sugar sources for biomass growth [19]. Consequently, reducing the concentration of substrate in the must results in a decrease in the ethanol content of fermented apple drinks subjected to micro-oxygenation. On the other hand, a properly selected dose of oxygen added to the must before fermentation and also at the beginning of fermentation contributes to the proper cellular structure of yeast [2]. Once properly structured, yeast cells are protected from the 
increasing alcohol concentration, although in ciders the ethanol concentration is too low to observe this phenomenon. It can be assumed that the use of oxygenation of musts with a higher sugar content would contribute to increase the tolerance of yeast to ethanol. Thus, oxygenated cider would contain higher concentrations of ethanol. Based on the results presented by Petrozziello et al. [20], it can be concluded that the dose of oxygen introduced $(7 \mathrm{mg} / \mathrm{L}, 14 \mathrm{mg} / \mathrm{L}, 21 \mathrm{mg} / \mathrm{L}$, and $28 \mathrm{mg} / \mathrm{L}$ of consumed oxygen) also affects the concentration of ethanol in wines, which decreases with the increase in the amount of oxygen introduced. It was only at a concentration of $28 \mathrm{mg}$ of oxygen/L that a higher concentration of ethanol was observed.

Table 1. Impact of the type of oxygenation on oenological parameters of ciders.

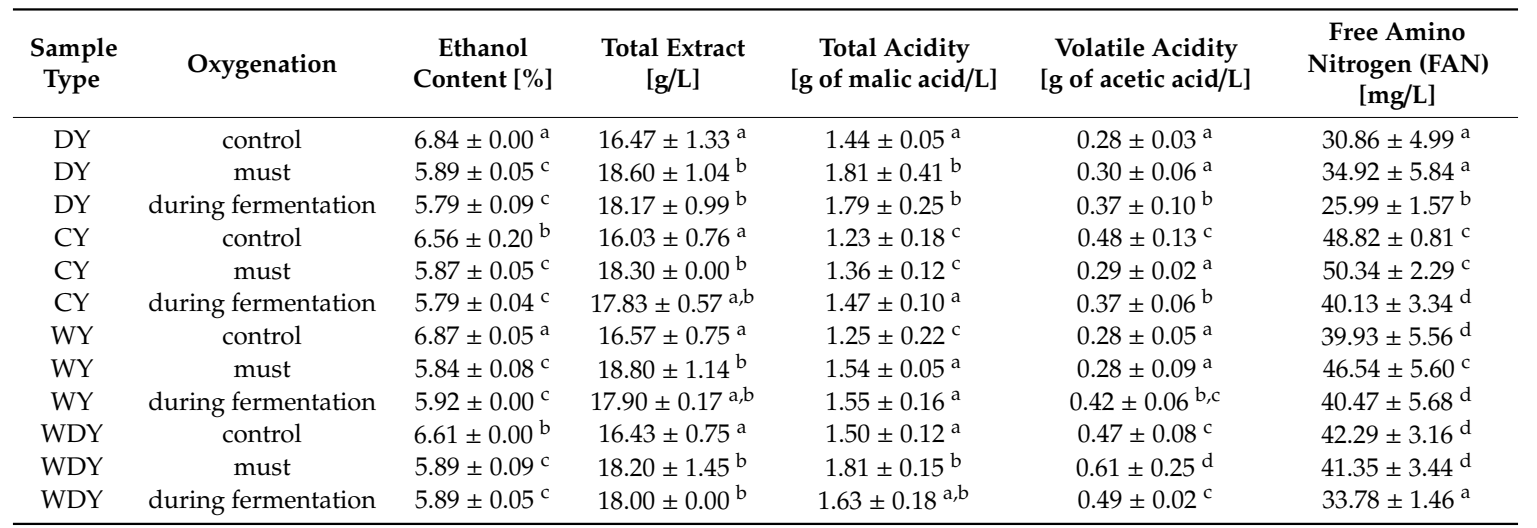

DY, distillery yeast; $C Y$, cider yeast; WY, wine yeast, WDY, wild yeast. Means marked with the same letter in a column are not significantly different at $p<0.05, \mathrm{n}=3$.

Different relationships were observed for the extract and total acidity. It was found that in the oxygenated ciders (both at the must production and at the fermentation stages), more extract remained in comparison to the control samples. The observed phenomenon was independent of the yeast strain used for fermentation. A larger amount of extract may be caused by an increase in the content of sugar-free compounds that form the extract. This proves that a sufficiently long fermentation process may allow the almost complete use of the available sugars, regardless of the yeast strain [2]. According to research by Satora et al. [21], the presence of oxygen may cause an increase in the content of carbonyl compounds, which is mainly caused by the oxidation of ethanol. The increase in extract concentration may have been associated with quantitative changes in the profile of polyphenols and aroma compounds that occurred after the application of oxygenation.

Sirén et al. [16] observed a slight increase of acidity in wines subjected to oxygenation, similar to the results of this study. Based on research by Petrozziello et al. [20], it can be argued that the concentration of oxygen introduced into a wine has an impact on total acidity. Oxygenation also increases the number of yeast cells, which can lead to an increase in the concentration of byproducts of the fermentation process, such as organic acids. The main secondary end product of alcohol fermentation is succinic acid, but low concentrations of pyruvic, malic, fumaric, oxaloacetic, citric, $\alpha$-ketoglutaric, glutamic, propionic, and lactic acids are also present [22].

The obtained results for volatile acidity (Table 1) are ambiguous, but the values did not exceed the permissible concentration of $1.3 \mathrm{~g}$ acetic acid/L [23]. The volatile acidity of ciders fermented with distillery yeast and wine yeast was similar. The oxygenation of these samples at the must stage did not affect the level of volatile acidity, but oxygenation during fermentation significantly increased it. The control samples fermented with cider yeast were characterized by high volatile acidity, which decreased after oxygenation. Ciders prepared using wild yeast also had high volatile acidity, and oxygenation at the must stage further increased it significantly (Table 1). Research conducted by Du Toit [1] confirmed that oxygenation led to higher acetic acid bacteria counts; however, no increase in volatile acidity was observed in South African Pinotage wine. 
Oxygenation slightly affected the use of FAN (Table 1). Significant differences (over 20\% compared to the control samples) were noticed only in the case of samples oxygenated in the initial period of fermentation and produced with wild yeast.

\subsection{The Effect of Oxygenation on Polyphenol Content and Cider Antioxidant Activity}

The polyphenolic profile of apples, and thus cider, depends on apple variety, climate, and degree of ripeness, storage conditions, and processing of the fruit. It is assumed that among the various classes of polyphenols in apples, the highest proportion consists of procyanidins (40-89\%). Much lower concentrations of hydroxycinnamic acid, dihydrochalkones, flavonols, anthocyanins, and flavan-3-ols are found [24]. Based on the results of this research and the available literature, it can be concluded that ciders are a source of phenolic compounds, but in comparison with other alcoholic beverages, e.g., wines, they show relatively weak antioxidant properties [24].

Oxygenation at the must stage caused a slight increase of antioxidant activity only in the samples fermented with distillery yeast and cider yeasts. The use of oxygenation at the fermentation stage led to a reduction of the antioxidant activity and total polyphenols content, regardless of the yeast strain used (Table 2). This decrease could have been caused by the reaction of quinones (oxidation products of phenolic compounds) with other phenols, resulting in the formation of new larger molecules. These polymers usually have a lower redox potential compared to that of their precursors $[25,26]$. A decrease of anthocyanin content in oxygenated wines is also observed, and its rate depends on the amount of oxygen supplied [20,27]. Cano-López et al. [28] showed how different wines were differently affected by oxidation. They reported that micro-oxygenated wines had a higher percentage of new anthocyanin-derived pigments, whose formation was more favored in wines with the highest total phenol content. These pigments, in turn, significantly increased wine color intensity [28].

Table 2. Impact of the type of oxygenation on polyphenol content and antioxidant activity of ciders.

\begin{tabular}{|c|c|c|c|c|c|c|}
\hline $\begin{array}{l}\text { Sample } \\
\text { Type }\end{array}$ & Oxygenation & $\begin{array}{c}\text { AOX [mg of } \\
\text { Trolox/100 mL] }\end{array}$ & $\begin{array}{c}\text { TPC }[\mathrm{mg} \text { of } \\
\text { Catechin } / 100 \mathrm{~mL}]\end{array}$ & $\begin{array}{l}\text { Chlorogenic } \\
\text { Acid }[\mathrm{mg} / \mathrm{L}]\end{array}$ & $\begin{array}{l}\text { Catechin } \\
{[\mathrm{mg} / \mathrm{L}]}\end{array}$ & $\begin{array}{l}\text { Phloridzin } \\
{[\mathrm{mg} / \mathrm{L}]}\end{array}$ \\
\hline DY & control & $57.23 \pm 2.38^{a}$ & $12.31 \pm 0.52^{\mathrm{a}}$ & $0.24 \pm 0.00^{\mathrm{a}}$ & $0.82 \pm 0.07^{\mathrm{a}}$ & $0.23 \pm 0.08^{a}$ \\
\hline DY & during fermentation & $56.26 \pm 1.45^{\mathrm{a}}$ & $11.89 \pm 0.13^{a}$ & $0.20 \pm 0.01^{c}$ & $0.60 \pm 0.10^{c}$ & - \\
\hline CY & control & $70.34 \pm 0.79^{c}$ & $14.25 \pm 0.47^{b, d}$ & $0.15 \pm 0.02^{d}$ & $0.56 \pm 0.08^{c}$ & $0.24 \pm 0.00^{a}$ \\
\hline CY & must & $72.27 \pm 1.87^{\mathrm{c}}$ & $15.69 \pm 0.62^{c}$ & $0.14 \pm 0.00^{\mathrm{d}}$ & $0.31 \pm 0.02^{\mathrm{d}}$ & - \\
\hline WY & control & $66.54 \pm 2.80^{d}$ & $13.40 \pm 0.31^{b}$ & $0.12 \pm 0.01^{\mathrm{e}}$ & $0.82 \pm 0.03^{\mathrm{a}}$ & $0.15 \pm 0.01^{b}$ \\
\hline WY & must & $65.07 \pm 2.95^{b, d}$ & $14.82 \pm 0.28^{\mathrm{d}}$ & $0.14 \pm 0.02 \mathrm{~d}$ & $0.25 \pm 0.02^{\mathrm{e}}$ & $0.10 \pm 0.01^{\mathrm{c}}$ \\
\hline WY & during fermentation & $64.30 \pm 1.46^{\mathrm{d}}$ & $12.45 \pm 0.45^{\mathrm{a}}$ & $0.15 \pm 0.01^{\mathrm{d}}$ & $0.40 \pm 0.08^{\mathrm{d}}$ & - \\
\hline WDY & control & $57.24 \pm 1.54^{\mathrm{a}}$ & $11.82 \pm 0.46^{\mathrm{a}}$ & $0.10 \pm 0.01^{\mathrm{f}}$ & $0.62 \pm 0.02^{\mathrm{c}}$ & $0.62 \pm 0.02^{d}$ \\
\hline WDY & must & $56.61 \pm 0.50^{\mathrm{a}}$ & $11.59 \pm 0.15^{\mathrm{a}}$ & $0.10 \pm 0.01^{\mathrm{f}}$ & $0.22 \pm 0.09^{b}$ & - \\
\hline
\end{tabular}

TPC, total polyphenol content; AOX, antioxidant activity. Means marked with the same letter in a column are not significantly different at $p<0.05, \mathrm{n}=3$.

Increases in antioxidant activity and/or polyphenol content were observed in several tests. The first one of these was conducted with fermented samples from either distillery yeast or cider yeast. These samples were oxygenated during the must production stage. A higher concentration of antioxidant activity was found compared to the control samples. Another exception was musts fermented with wine yeast. These showed a higher content of total polyphenolic compounds (TPC) compared with the control. By using oxygenation of the must before and during fermentation, a higher concentration of chlorogenic acid was observed in samples fermented with wine yeast. The last exception was the higher catechin concentration in the samples subjected to oxygenation during fermentation with cider yeast. As a result of oxygenation, the structure of polyphenols may change, for example, the distribution of condensed polyphenols, with the release of chlorogenic acid that synergizes with catechin $[29,30]$. The exceptions described above concern musts fermented with noble 
yeast. Oxygenation in fermented musts in the presence of wild yeast resulted in a decrease in the concentration of the analyzed polyphenols. It is possible that noble yeast has a higher resistance to polyphenol oxidation. The use of oxygenation had no effect or caused a decrease in the concentration of caffeic acid and phloridin in all samples analyzed.

\subsection{The Effect of Oxygenation on the Profile of Volatile Cider Compounds}

Oxidation may improve wine flavor, increasing its fruity aroma and decreasing the vegetal notes. This decrease is not connected with the reduction of typical herbaceous compounds (C6 compounds); however, the reduction of other compounds, e.g., oxidized pyrazines and thiols, may contribute to appearance the herbaceous flavor of wines [31]. As a result of using must oxygenation (Table 3), the content of esters and alcohols in the ciders we analyzed mostly increased. However, due to oxygenation during fermentation, a decrease in the concentration of these volatile components was usually observed. The above relationship may be related to the formation of esters and higher alcohols during fermentation and to their oxidation as a result of the use of oxygenation. The exceptions were isobutyl acetate, 2-methylbutanol, and diethyl acetal, whose concentrations were higher in oxygenated wines compared to the controls. Hernández-Orte et al. [32] observed an increase in the concentration of esters, including ethyl acetate and isobutyl acetate, in Tempranillo wines, which were micro-oxygenated after fermentation. Different results were presented by Du Toit [1], who showed a reduction in isobutyl acetate concentration in South African Pinotage wine after excessive oxidation. Based on research by Perez-Magarino et al. [33], a reduction in the concentration of short-chain esters, acetates, and C6 alcohols was found, as well as an increase in the concentration of succinic acid derivatives and long-chain esters in wine obtained using the combined effect of different chips and the application of oxidation before malolactic fermentation. These changes caused a decrease in green taste, acidity, and bitterness [18].

Oxidation of musts before and during fermentation did not show the same effect on the concentration of terpenes in the samples we analyzed, the content of which increased in some cases (pinocarveol, cider yeast and wild yeast; terpen-4-ol, distillery yeast; geraniol, wine yeast and wild yeast; eugenol, wild yeast; and isoeugenol, cider yeast) and decreased in others (Table 4). A decrease in concentration of eugenol, guaiacol, and isoeugenol, among others, was observed by Hernández-Orte et al. [32] in Tempranillo wines, micro-oxygenated after fermentation. In our research, the concentration of eugenol increased relative to the control when using must oxygenation and decreased when musts were oxygenated during fermentation. Based on research by Ferreira et al. [34], it was discovered that the use of wine oxygenation contributed to an increase of eugenol concentration, which consequently deepened the feeling of a woody aroma. Excessive oxygen also leads to the degradation of $\beta$-ionone and $\beta$-damascenone, which confer a violet and a ripe fruit aroma, respectively. Also in our research (with two exceptions), a decrease in the concentration of these compounds was observed after the application of oxygenation. Ferreira et al. [35] confirmed a decrease in the levels of terpene alcohols due to the synergistic effect of increasing both temperature and $\mathrm{O}_{2}$ content while at low pH levels. 
Table 3. Impact of the type of oxygenation on volatile compounds concentration in ciders.

\begin{tabular}{|c|c|c|c|c|c|c|c|c|c|c|}
\hline \multirow{2}{*}{$\begin{array}{l}\text { Sample } \\
\text { Type }\end{array}$} & \multirow[t]{2}{*}{ Oxygenation } & Ethyl Acetate & $\begin{array}{l}\text { Isobutyl } \\
\text { Acetate }\end{array}$ & $\begin{array}{l}\text { Isopentyl } \\
\text { Acetate }\end{array}$ & Hexyl Acetate & $\begin{array}{c}\text { Ethyl } \\
\text { Hexanoate }\end{array}$ & 3-methyl-Butanol & 2-methyl-Butanol & Isobutanol & $\begin{array}{l}\text { Diethyl } \\
\text { Acetal }\end{array}$ \\
\hline & & \multicolumn{9}{|c|}{$\mathrm{mg} / \mathrm{L}$} \\
\hline DY & $\mathrm{C}$ & $80.87 \pm 10.60^{\mathrm{a}}$ & $1.38 \pm 0.04^{\mathrm{a}}$ & $0.48 \pm 0.08^{a}$ & $0.11 \pm 0.01^{\mathrm{a}}$ & $0.27 \pm 0.05^{\mathrm{a}}$ & $245.82 \pm 3.22^{\mathrm{a}}$ & $171.27 \pm 2.35^{\mathrm{a}}$ & $169.66 \pm 17.53^{\mathrm{a}}$ & $2.31 \pm 0.07^{\mathrm{a}}$ \\
\hline DY & $\mathrm{M}$ & $44.27 \pm 8.20^{b}$ & $1.72 \pm 0.02^{b}$ & $1.09 \pm 0.24^{b}$ & $0.15 \pm 0.02^{\mathrm{b}, \mathrm{e}}$ & $0.31 \pm 0.07^{\mathrm{a}, \mathrm{d}}$ & $231.01 \pm 4.36^{\mathrm{b}}$ & $173.58 \pm 5.63^{a}$ & $159.47 \pm 10.45^{\mathrm{a}}$ & $2.83 \pm 0.12^{b, e}$ \\
\hline DY & $\mathrm{DF}$ & $27.13 \pm 1.86^{c}$ & $1.59 \pm 0.02^{c}$ & $0.45 \pm 0.01^{\mathrm{a}}$ & $0.08 \pm 0.01^{c}$ & $0.00 \pm 0.00^{b}$ & $246.83 \pm 4.06^{\mathrm{a}, \mathrm{b}}$ & $178.53 \pm 2.60^{a}$ & $165.86 \pm 9.59^{\mathrm{a}}$ & $2.52 \pm 0.05^{c}$ \\
\hline $\mathrm{CY}$ & C & $54.63 \pm 3.38^{d}$ & $1.29 \pm 0.04^{\mathrm{d}}$ & $0.37 \pm 0.26^{c}$ & $0.16 \pm 0.01^{b}$ & $0.55 \pm 0.04^{c}$ & $154.05 \pm 2.20^{c}$ & $97.05 \pm 2.25^{b}$ & $58.80 \pm 3.64^{b}$ & $1.92 \pm 0.05^{\mathrm{d}}$ \\
\hline $\mathrm{CY}$ & $M$ & $28.26 \pm 0.20^{c}$ & $1.65 \pm 0.02^{\mathrm{e}}$ & $0.21 \pm 0.02^{d}$ & $0.20 \pm 0.01^{d}$ & $0.37 \pm 0.00^{\mathrm{d}}$ & $163.49 \pm 5.12^{d}$ & $114.27 \pm 4.24^{\mathrm{c}}$ & $76.09 \pm 5.36^{c}$ & $2.77 \pm 0.06^{b}$ \\
\hline $\mathrm{CY}$ & DF & $21.92 \pm 1.86^{\mathrm{e}}$ & $1.79 \pm 0.01^{\mathrm{f}}$ & $0.11 \pm 0.02 \mathrm{e}$ & $0.14 \pm 0.01^{\mathrm{b}, \mathrm{e}}$ & $0.13 \pm 0.01 \mathrm{e}^{\mathrm{e}}$ & $155.91 \pm 3.98^{c}$ & $114.01 \pm 2.80^{c}$ & $73.59 \pm 6.81^{c}$ & $3.00 \pm 0.07^{\mathrm{e}}$ \\
\hline WY & $\mathrm{C}$ & $55.86 \pm 4.85^{\mathrm{d}}$ & $1.45 \pm 0.02^{\mathrm{a}}$ & $0.16 \pm 0.01 \mathrm{e}$ & $0.13 \pm 0.01 \mathrm{e}^{\mathrm{e}}$ & $0.30 \pm 0.06^{\mathrm{a}}$ & $154.41 \pm 1.34^{c}$ & $109.49 \pm 1.12^{\mathrm{d}}$ & $61.97 \pm 2.29^{b}$ & $2.60 \pm 0.10^{c}$ \\
\hline WY & $\mathrm{M}$ & $32.45 \pm 0.93^{f}$ & $1.76 \pm 0.02^{b}$ & $0.29 \pm 0.20^{\mathrm{d}, \mathrm{e}}$ & $0.17 \pm 0.01^{b}$ & $0.22 \pm 0.05^{\mathrm{a}}$ & $149.60 \pm 1.77^{c}$ & $109.72 \pm 1.21^{\mathrm{d}}$ & $68.74 \pm 2.36^{\mathrm{c}}$ & $3.49 \pm 0.67^{\mathrm{e}, \mathrm{f}}$ \\
\hline WY & $\mathrm{DF}$ & $29.94 \pm 8.44^{\mathrm{c}, \mathrm{e}, \mathrm{f}}$ & $1.72 \pm 0.03^{b}$ & $0.08 \pm 0.03^{f}$ & $0.15 \pm 0.01^{\mathrm{b}, \mathrm{e}}$ & $0.12 \pm 0.10^{\mathrm{e}, \mathrm{f}}$ & $140.92 \pm 3.00 \mathrm{e}$ & $109.33 \pm 2.73^{d}$ & $71.48 \pm 1.76^{c}$ & $3.66 \pm 0.25^{\mathrm{e}}$ \\
\hline WDY & $\mathrm{C}$ & $41.82 \pm 3.98^{b}$ & $1.52 \pm 0.03^{c}$ & $0.15 \pm 0.01 \mathrm{e}^{\mathrm{e}}$ & $0.11 \pm 0.01^{\mathrm{a}}$ & $0.18 \pm 0.04^{\mathrm{a}, \mathrm{e}, \mathrm{f}}$ & $139.23 \pm 6.85^{\mathrm{e}}$ & $91.34 \pm 2.08^{\mathrm{e}}$ & $75.12 \pm 3.30^{c}$ & $2.75 \pm 0.10^{b}$ \\
\hline WDY & $\mathrm{M}$ & $54.81 \pm 12.40^{\mathrm{d}}$ & $1.76 \pm 0.04^{\mathrm{f}}$ & $0.24 \pm 0.12^{\mathrm{d}}$ & $0.13 \pm 0.03^{a, b}$ & $0.16 \pm 0.0^{f}$ & $140.02 \pm 1.60^{\mathrm{e}}$ & $98.06 \pm 1.19^{b}$ & $80.92 \pm 9.20^{c}$ & $3.17 \pm 0.08^{\mathrm{e}}$ \\
\hline WDY & $\mathrm{DF}$ & $31.55 \pm 1.20^{\mathrm{f}}$ & $1.79 \pm 0.04^{\mathrm{f}}$ & $0.14 \pm 0.03 \mathrm{e}^{\mathrm{e}}$ & $0.11 \pm 0.01^{\mathrm{a}}$ & $0.12 \pm 0.01 \mathrm{e}^{\mathrm{e}}$ & $156.64 \pm 1.68^{c}$ & $129.72 \pm 3.00^{f}$ & $123.13 \pm 4.34^{\mathrm{d}}$ & $3.41 \pm 0.11^{\mathrm{f}}$ \\
\hline
\end{tabular}

C, control, M, must; DF, during fermentation. Means marked with the same letter in a column are not significantly different at $p<0.05, \mathrm{n}=3$. 
Table 4. Impact of the type of oxygenation on terpenes concentration in ciders.

\begin{tabular}{|c|c|c|c|c|c|c|c|c|c|}
\hline \multirow{2}{*}{ Sample Type } & \multirow{2}{*}{ Oxygenation } & Pinocarveol & Camphor & Terpen-4-ol & Geraniol & Eugenol & $\beta$-Damascenone & Isoeugenol & $\beta$-Ionone \\
\hline & & \multicolumn{8}{|c|}{$\mathrm{mg} / \mathrm{L}$} \\
\hline DY & $\mathrm{C}$ & $1.03 \pm 0.11^{\mathrm{a}}$ & $0.06 \pm 0.01^{\mathrm{a}}$ & $0.54 \pm 0.04^{\mathrm{a}}$ & $0.13 \pm 0.05^{a, b}$ & $0.07 \pm 0.02^{\mathrm{a}}$ & $0.04 \pm 0.00^{\mathrm{a}}$ & $3.83 \pm 0.18^{a, c}$ & $0.09 \pm 0.01^{\mathrm{c}}$ \\
\hline DY & $\mathrm{M}$ & $1.03 \pm 0.03^{a}$ & $0.03 \pm 0.00^{b}$ & $1.20 \pm 0.04^{b}$ & $0.14 \pm 0.02^{a}$ & $0.24 \pm 0.03^{b}$ & $0.04 \pm 0.00^{a}$ & $3.34 \pm 0.03^{b}$ & $0.07 \pm 0.01^{\circ}$ \\
\hline DY & $\mathrm{DF}$ & $0.92 \pm 0.02^{b}$ & $0.03 \pm 0.00^{b}$ & $0.56 \pm 0.01^{\mathrm{a}}$ & $0.11 \pm 0.00^{\mathrm{a}, \mathrm{b}}$ & $0.07 \pm 0.02^{\mathrm{a}}$ & $0.04 \pm 0.00^{a}$ & $3.67 \pm 0.03^{a, c}$ & $0.08 \pm 0.00^{\circ}$ \\
\hline $\mathrm{CY}$ & $\mathrm{C}$ & $0.58 \pm 0.03^{c}$ & $0.05 \pm 0.00^{a}$ & $1.95 \pm 0.11^{\mathrm{c}}$ & $0.10 \pm 0.01^{b, c}$ & $0.25 \pm 0.01^{b}$ & $0.05 \pm 0.00^{b}$ & $3.64 \pm 0.20^{a, c}$ & $0.08 \pm 0.01^{\circ}$ \\
\hline $\mathrm{CY}$ & $\mathrm{M}$ & $0.60 \pm 0.03^{c}$ & $0.03 \pm 0.00^{b}$ & $1.88 \pm 0.08^{c}$ & $0.09 \pm 0.01^{b, c}$ & $0.33 \pm 0.03^{c}$ & $0.04 \pm 0.00^{a}$ & $3.88 \pm 0.21^{\mathrm{a}, \mathrm{c}}$ & $0.09 \pm 0.01$ \\
\hline $\mathrm{CY}$ & DF & $0.68 \pm 0.01^{\mathrm{d}}$ & $0.03 \pm 0.00^{b}$ & $0.96 \pm 0.06^{\mathrm{d}}$ & $0.08 \pm 0.01^{c}$ & $0.24 \pm 0.02^{b}$ & $0.04 \pm 0.00^{a}$ & $3.66 \pm 0.14^{a, c}$ & $0.08 \pm 0.00^{\circ}$ \\
\hline WY & $\mathrm{C}$ & $0.67 \pm 0.06^{\mathrm{d}}$ & $0.04 \pm 0.00^{b}$ & $1.04 \pm 0.03^{\mathrm{e}}$ & $0.08 \pm 0.00^{c}$ & $0.16 \pm 0.01^{c}$ & $0.04 \pm 0.00^{a}$ & $3.42 \pm 0.31^{c}$ & $0.06 \pm 0.01^{b}$ \\
\hline WY & $\mathrm{M}$ & $0.60 \pm 0.02^{c, d}$ & $0.02 \pm 0.00^{\mathrm{c}}$ & $1.45 \pm 0.05^{\mathrm{f}}$ & $0.09 \pm 0.01^{b, c}$ & $0.28 \pm 0.03^{b}$ & $0.03 \pm 0.00^{c}$ & $3.06 \pm 0.13^{d}$ & $0.07 \pm 0.00^{\mathrm{b}}$ \\
\hline WY & $\mathrm{DF}$ & $0.67 \pm 0.03^{d}$ & $0.03 \pm 0.00^{b}$ & $0.81 \pm 0.07 \mathrm{~g}$ & $0.09 \pm 0.01^{b, c}$ & $0.14 \pm 0.02^{d}$ & $0.04 \pm 0.00^{a}$ & $2.39 \pm 0.08^{\mathrm{e}}$ & $0.06 \pm 0.01^{\mathrm{b}}$ \\
\hline WDY & $\mathrm{C}$ & $0.45 \pm 0.04^{\mathrm{e}}$ & $0.03 \pm 0.00^{b}$ & $0.50 \pm 0.09^{a}$ & $0.08 \pm 0.00^{\mathrm{c}}$ & $0.10 \pm 0.00 \mathrm{e}$ & $0.03 \pm 0.00^{c}$ & $3.83 \pm 0.25^{\mathrm{a}, \mathrm{c}}$ & $0.07 \pm 0.02$ \\
\hline WDY & M & $0.55 \pm 0.03^{c}$ & $0.02 \pm 0.00^{c}$ & $0.52 \pm 0.11^{\mathrm{a}}$ & $0.08 \pm 0.01^{c}$ & $0.19 \pm 0.01^{f}$ & $0.03 \pm 0.00^{c}$ & $3.74 \pm 0.14^{\mathrm{a}}$ & $0.06 \pm 0.01^{b}$ \\
\hline WDY & DF & $1.04 \pm 0.09^{\mathrm{a}}$ & $0.03 \pm 0.00^{b}$ & $0.19 \pm 0.04^{h}$ & $0.09 \pm 0.00^{b, c}$ & $0.12 \pm 0.01^{d}$ & $0.03 \pm 0.00^{c}$ & $4.13 \pm 0.11^{\mathrm{f}}$ & $0.08 \pm 0.01^{\mathrm{a}}$ \\
\hline
\end{tabular}

Means marked with the same letter in a column are not significantly different at $p<0.05, \mathrm{n}=3$. 


\section{Conclusions}

Oxidation of musts before and during fermentation reduced ethanol concentration in the tested samples. In addition, a higher concentration of extract as well as higher total and volatile acidity levels were observed in the oxygenated samples. The use of oxygenation in most of the studied ciders caused a reduction in polyphenols and oxidative activity, especially in samples fermented with wild yeast. Perhaps, noble yeast has a higher tolerance to oxygen present in must. As a result of using must oxygenation, the content of esters and alcohols in the ciders we analyzed mostly increased. However, due to must oxygenation during fermentation, a decrease in the concentration of these volatile components was usually observed. The above dependence may be related to the formation of esters and higher alcohols during fermentation, which may be oxidized as a result of the use of oxygenation during fermentation; oxygenation can also cause oxidative stress of yeast, which consequently produces fewer aromatic compounds. The oxygenation of the samples did not show the same effect on terpene concentration in the analyzed ciders, the content of which increased in some cases and decreased in others.

Author Contributions: Conceptualization, T.T. and P.S.; methodology, T.T., P.S., A.D.-C., and M.J.; validation, T.T., P.S., A.D.-C., and M.J.; formal analysis, T.T., P.S., A.D.-C., and M.J.; investigation, T.T. and M.J.; resources, T.T.; data curation, T.T. and M.J.; writing—original draft preparation, T.T. and M.J.; writing —review and editing, T.T. and A.D.-C.; visualization, T.T.; supervision, T.T.; project administration, T.T.; funding acquisition, T.T. All authors have read and agreed to the published version of the manuscript.

Funding: This study received financial support in the years 2016-2019 as the research project 2015/19/B/NZ9/01352 funded by the National Science Centre (Krakow, Poland).

Conflicts of Interest: The authors declare no conflict of interest.

\section{References}

1. Du Toit, W.; Marais, J.; Pretorius, I.S.; Du Toit, M. Oxygen in must and wine: A review. S. Afr. J. Enol. Vitic. 2006, 57, 76-94. [CrossRef]

2. Tarko, T.; Kostrz, M.; Duda-Chodak, A.; Semik-Szczurak, D.; Sroka, P.; Senczyszyn, T. The effect of apple cultivars and yeast strains on selected quality parameters and antioxidant activity of fermented apple beverages. CyTA-J. Food 2018, 16, 892-900. [CrossRef]

3. Li, H.; Guo, A.; Wang, H. Mechanisms of oxidative browning of wine. Food Chem. 2008, 108, 1-13. [CrossRef]

4. Valero, E.; Millan, C.; Ortega, J.M. Influence of oxygen addition during growth phase on the biosynthesis of lipids in Saccahromyces cerevisiae (M330-9) in enological fermentations. J. Biosc. Bioeng. 2001, 92, 33-38. [CrossRef]

5. Varela, C.; Torrea, D.; Schmidt, S.A.; Ancin-Azpilicueta, C.; Henschke, P.A. Effect of oxygen and lipid supplementation on the volatile composition of chemically defined medium and Chardonnay wine fermented with Saccharomyces cerevisiae. Food Chem. 2020, 135, 2863-2871. [CrossRef] [PubMed]

6. Gonzalez-Marco, A.; Jimenez-Moreno, N.; Ancin-Azpilicueta, C. Concentration of volatile compounds in Chardonnay wine fermented in stainless steel tanks and oak barrels. Food Chem. 2008, 108, 213-219. [CrossRef]

7. Varela, C.; Barker, A.; Tran, T.; Borneman, A.; Curtin, C. Sensory profile and volatile aroma composition of reduced alcohol Merlot wines fermented with Metschnikowia pulcherrima and Saccharomyces uvarum. Int. J. Food Microb. 2017, 252, 1-9. [CrossRef] [PubMed]

8. Rudnitskaya, A.; Schmidtke, L.M.; Delgadillo, I.; Legin, A.; Scollary, G. Study of the influence of micro-oxygenation and oak chip maceration on wine composition using an electronic tongue and chemical analysis. Anal. Chim. Acta. 2009, 642, 235-245. [CrossRef] [PubMed]

9. Schmidtke, L.M.; Clark, A.C.; Geoff, R.S. Micro-Oxygenation of Red Wine: Techniques, applications, and outcomes. Crit. Rev. Food Sci. Nutr. 2011, 51, 115-131. [CrossRef] [PubMed]

10. Gómez-Plaza, E.; Bautista-Ortín, A.B. Emerging Technologies for Aging Wines: Use of Chips and Micro-Oxigenation. In Red Wine Technology; Morata, A., Ed.; Academic Press: Madrid, Spain, 2019; pp. 150-152. 
11. Organisation Internationale de la Vigne et du Vin (O.I.V.). Compendium of International Methods of Wine and Must Analysis; Organisation Internationale de la Vigne et du Vin: Paris, France, 2019; pp. 154-196.

12. Spedding, G.; Harrison, N.R.; Ganske, F.; Dell, E.J. A new way to test the free amino nitrogen content in alcoholic beverages with the SPECTROstarNano. BMG Labtech. 2012, 5, 1-2.

13. Tarko, T.; Duda-Chodak, A.; Sroka, P.; Satora, P.; Tuszynski, T. Production of flavored apple chips of high antioxidant activity. J. Food Process. Preserv. 2010, 34, 728-742. [CrossRef]

14. Tarko, T.; Duda-Chodak, A.; Sroka, P.; Satora, P.; Semik-Szczurak, D.; Wajda, Ł. Diversity and bioavailability of fruit polyphenols. J. Food Nutr. Res. 2017, 56, 167-178.

15. Grützman, S.; Caliari, A.V.; Sganzerla, M.; Godoy, H.T. Volatile composition of Merlot red wine and its contribution to the aroma: Optimization and validation of analytical method. Talanta 2017, 174, 752-766.

16. Sirén, K.; Sirén, K.; Sirén, J. Evaluation of organic and inorganic compounds levels of red wines processed from Pinot Noir grapes. Anal. Chem. Res. 2015, 3, 26-36. [CrossRef]

17. Fell, A.; Dykes, S.; Nicolau, L.; Kilmartin, P. Electrochemical microoxidation of red wine. Am. J. Enol. Vitic. 2007, 58, 443-450.

18. Anli, R.E.; Cavuldak, Ö.A. A review of microoxigenation application in wine. J. Inst. Brew. 2013, 118, 368-385. [CrossRef]

19. Sáenz-Navajas, M.P.; Henschen, C.; Cantu, A.; Watrelot, A.A.; Waterhouse, A.L. Understanding microoxygenation: Effect of viable yeasts and sulfur dioxide levels on the sensory properties of a Merlot red wine. Food Res. Int. 2018, 108, 505-515. [CrossRef] [PubMed]

20. Petrozziello, M.; Torchio, F.; Piano, F.; Giacosa, S.; Ugliano, M.; Bosso, A.; Rolle, L. Impact of Increasing Levels of Oxygen Consumption on the Evolution of Color, Phenolic, and Volatile Compounds of Nebbiolo Wines. Front. Chem. 2018, 6, 137. [CrossRef] [PubMed]

21. Satora, P.; Semik-Szczurak, D.; Tarko, T.; Bułdys, A. Influence of selected Saccharomyces and Schizosaccharomyces strains and their mixed cultures on chemical composition of apple wines. J. Food Sci. 2018, 83, 424-431. [CrossRef] [PubMed]

22. Riekstina-Dolge, R.; Kruma, Z.; Dimins, F.; Straumite, E.; Karklina, D. Phenolic composition and sensory properties of ciders produced from Latvian apples. Proc. Latv. Univ. Agr. 2014, 31, 39-45. [CrossRef]

23. Minister Rolnictwa i Rozwoju Wsi, Dziennik Ustaw. Rozporzadzenie Ministra Rolnictwa $i$ Rozwoju Wsi z Dnia 22 Maja 2013 r. w Sprawie Rodzajów Fermentowanych Napojów Winiarskich oraz Szczegótowych Wymagań Organoleptycznych, Fizycznych i Chemicznych, jakie Powinny Spetniać te Napoje; Rządowe Centrum Legislacji: Warsaw, Poland, 2013.

24. Kwaśniewska, D.; Wieczorek, D. Ocena właściwości przeciwutleniających cydrów. Food Sci. Technol. Q. 2016, 6, 80-89. [CrossRef]

25. Gómez-Plaza, E.; Cano-López, M. A review on microoxygenation of red wines: Claims, benefits and the underlying chemistry. Food Chem. 2011, 125, 1131-1140. [CrossRef]

26. Oliviera, C.M.; Ferreira, A.C.S.; De Freitas, V.; Silva, A.M.S. Oxidation mechanisms occurring in wines. Food Res. Int. 2011, 44, 1115-1126. [CrossRef]

27. Arapitsas, A.; Scholz, M.; Vrhovsek, U.; Di Blasi, S.; Biondi, A.; Masuero, D.; Perenzoni, D.; Rigo, A.; Mattivi, F. A metabolomic approach to the study of wine micro-oxygenation. PLoS ONE 2012, 7. [CrossRef] [PubMed]

28. Cano-López, M.; Pardo-Minguez, F.; Schmauch, G.; Saucier, C.; Teissedre, P.L.; Lopez-Roca, J.M.; Gomez-Plaza, E. Effect of micro-oxygenation on color and anthocyanin-related compounds of wines with different phenolic contents. J. Agric. Food. Chem. 2008, 56, 5932-5941. [CrossRef] [PubMed]

29. Laaksonen, O.; Kuldjärv, R.; Paalme, T.; Virkki, M.; Yang, B. Impact of apple cultivar, ripening stage, fermentation type and yeast strain on phenolic composition of apple ciders. Food Chem. 2017, 233, $29-37$. [CrossRef] [PubMed]

30. Lili, X.; Qianyu, Y.; Feng'e, B.; Heng, Z.; Yuxin, Y. Melatonin treatment enhances the polyphenol content and antioxidant capacity of red wine. Hort. Plant. J. 2018, 4, 144-150. [CrossRef]

31. Parpinello, G.; Plumejeau, F.; Maury, C.; Versari, A. Effect of micro-oxygenation on sensory characteristics and consumer preference of Cabernet Sauvignon wine. J. Sci. Food Agric. 2011, 92, 1238-1244. [CrossRef] [PubMed]

32. Hernández-Orte, P.; Lapena, A.C.; Escudero, A.; Astrain, J.; Baron, J.; Pardo, I.; Polo, L.; Ferrer, S.; Cacho, J.; Ferreira, V. Effect of micro-oxygenation on the evolution of aromatic compounds in wines: Malolactic fermentation and ageing in wood. LWT-Food Sci. Technol. 2009, 42, 391-401. [CrossRef] 
33. Perez-Magarino, S.; Ortage-Heras, M.; Cano-Mozo, E.; Gonzalez-Sanjose, M.L. The influence of oak wood chips, micro-oxygenation treatment and grape variety on colour andanthocyanin and phenolic composition of red wines. J. Food Comp. Anal. 2009, 22, 204-211. [CrossRef]

34. Ferreira, V.; Escudero, A.; Lopez, R.; Cacho, J. Analytical characterization of the flavour of oxygen-spoiled wines through the gas chromatography-iontrap mass spectrometry of ultratrace odourants: Optimization of conditions. J. Chrom. Sci. 1998, 36, 331-339. [CrossRef]

35. Ferreira, A.C.; De Pinho, P.G.; Rodrigues, P.; Hogg, T.A. Kinetics of oxidative degradation of white wines and how they are affected by selected technological parameters. J. Agric. Food Chem. 2002, 50, 5919-5924. [CrossRef] [PubMed]

(C) 2020 by the authors. Licensee MDPI, Basel, Switzerland. This article is an open access article distributed under the terms and conditions of the Creative Commons Attribution (CC BY) license (http://creativecommons.org/licenses/by/4.0/). 